\title{
Efficacy and safety of bupropion for smoking cessation and reduction in schizophrenia: systematic review and meta-analysis*
}

Daniel Tai-yin Tsoi, Mamta Porwal and Angela Claire Webster

\section{Background}

The benefits and harms of bupropion as an aid for smoking cessation in schizophrenia remain uncertain.

\section{Aims \\ To summarise the current evidence for efficacy and safety of bupropion as treatment for nicotine dependence in schizophrenia. \\ Method \\ Systematic review and random-effects meta-analysis of randomised controlled trials (RCTs) comparing bupropion with placebo or alternative therapeutic control in adult smokers with schizophrenia.}

\section{Results}

Twenty-one reports from seven RCTs were included.

Biochemically verified self-reported smoking cessation rates after bupropion were significantly higher than placebo at the end of treatment (risk ratio $(\mathrm{RR})=2.57, P=0.004$ ) and at 6 months ( $R R=2.78, P=0.05)$. Expired carbon monoxide level was significantly lower with bupropion at the end of therapy $(P=0.002)$ but not at 6 months $(P=0.37)$. There was no significant difference in positive $(P=0.28)$ or negative symptoms $(P=0.49)$ between the bupropion and the placebo group.

\section{Conclusions}

Bupropion increases the rates of smoking abstinence in smokers with schizophrenia, without jeopardising their mental state.

\section{Declaration of interest}

None.
Tobacco dependence is one of the major causes of premature death and disability in the world. ${ }^{1}$ People with schizophrenia have three times the odds of ever smoking than the general population and their smoking cessation rates are lower than the smoking cessation rates in the general population. ${ }^{2}$ Furthermore, smokers with schizophrenia may smoke more heavily and extract more nicotine from each cigarette. ${ }^{3-5}$ Tobacco may also be used to alleviate some of the symptoms in schizophrenia and the side-effects of antipsychotic medications. ${ }^{6,7}$ Using nicotine to 'self-medicate', together with depressive symptoms, drug misuse, disorganised thinking and poor task persistence in people with schizophrenia, may explain the lower motivation and the greater difficulty for smoking cessation in these individuals. ${ }^{8}$ Because of the particular set of challenges they face in attempting to quit smoking, there is a need to investigate effective treatments for smoking cessation in people with schizophrenia. There is robust evidence supporting bupropion as a safe and effective treatment for nicotine dependence in the general population. ${ }^{9}$ Bupropion is an atypical antidepressant with both dopaminergic and adrenergic actions. ${ }^{10}$ Research suggests that bupropion acts as a non-competitive antagonist at the nicotinic acetycholinergic receptor. ${ }^{11}$ Bupropion may also have an effect on the brain reward system, which may contribute to its action on smoking cessation. ${ }^{12}$ However, the benefits and harms of bupropion as an aid for smoking cessation in schizophrenia remain uncertain. Smokers with schizophrenia have a more severe nicotine dependence compared with other smokers, and bupropion is metabolised by the cytochrome P450 system in the liver and it may interact with the commonly used antipsychotic medications metabolised by the same system. This, as well as bupropion's

*This work was presented as a poster at the 17th European Congress of Psychiatry, Lisbon, 2009. An expanded version of the review (including interventions other than bupropion) will appear in the Cochrane Library, issue 6, 2010. dopaminergic action, may adversely affect the mental state of individuals with schizophrenia. These uncertainties are reflected in treatment guidelines for smoking cessation in schizophrenia. In one guideline, the use of bupropion as a drug treatment for tobacco dependence was not recommended, as there was concern that bupropion may precipitate or exacerbate a psychotic relapse because of its pharmacodynamic and pharmacokinetic properties. $^{13}$

There is therefore a strong need for evidence regarding effective smoking cessation treatments for people with schizophrenia. There is evidence of benefit and few harms of bupropion in the general population, but there is uncertainty whether this benefit is generalisable and there are specific safety concerns for use of bupropion among individuals with schizophrenia. Thus, we aimed to systematically review and synthesise all current evidence of efficacy and safety of bupropion as a treatment for nicotine dependence in individuals with schizophrenia.

\section{Method}

\section{Inclusion criteria}

All randomised controlled trials (RCTs) comparing bupropion with placebo or with a different therapeutic control in adult smokers with a current diagnosis of schizophrenia according to either the ICD-10 $0^{14}$ or the DSM-IV ${ }^{15}$ were included. Trials using bupropion together with other co-interventions (either pharmacological or non-pharmacological) were also included and the trial control arms could be pharmacological or nonpharmacological or both. Trials that used bupropion for purposes other than smoking cessation or reduction, as well as trials which investigated people with other psychiatric diagnoses were excluded. However, we included studies of individuals with schizophrenia who had substance use disorders in addition to nicotine dependence, as the prevalence of these disorders among people with schizophrenia can be substantial. ${ }^{16}$ 


\section{Data sources and search strategy}

One of the authors (D.T.T.) searched the Cochrane Central Register of Controlled Trials (CENTRAL) of the Cochrane Library, MEDLINE, EMBASE and PsycINFO from inception to 7 March 2009. To locate unpublished studies, conference abstracts, records of trials held by the manufacturers of bupropion GlaxoSmithKline (www.gsk-clinicalstudyregister.com/) and reference lists of all relevant studies were searched. Full details of the search strategy are listed in the online supplement.

\section{Outcome measures}

The following outcome measures were included.

(a) Abstinence from smoking at the end of bupropion treatment. Abstinence was measured either by self-report or biochemical verification (such as expired carbon monoxide (CO) level) or both. In each study, we used the strictest available criteria to define abstinence. For instance, if both sustained abstinence and point-prevalence abstinence rates were presented, data for sustained abstinence were extracted in preference to point prevalence. In studies that used biochemical validation of abstinence, only those participants who met the criteria of cessation biochemically were classified as abstinent.

(b) Change in severity of smoking dependence at the end of bupropion treatment (reduction). Change in severity of smoking dependence was measured by change in expired CO level, self-reported reduction in number of cigarettes smoked or other biochemical measurement.

(c) Change in the mental state at the end of bupropion treatment, measured by change in positive, negative and depressive symptoms using validated measurement tools.

We also included abstinence and change in severity of smoking dependence after 6 months follow-up from the start of bupropion therapy. West et al suggested some common standards (the 'Russell Standard') for outcome criteria in smoking cessation trials including duration and definition of abstinence, the need for biochemical verification, use of intention-to-treat analysis, the way to handle protocol violators and the importance of masking. ${ }^{17}$ We chose 6 months because the Russell Standard states that a sustained period of abstinence for at least 6 months is required to provide confidence that abstinence will continue long term and that a degree of health benefit will be achieved. A report by the US Department of Health and Human Services also suggests that measuring abstinence at less than 6 months does not provide an accurate prediction of long-term cessation. ${ }^{18}$ The US Department of Health and Human Services Tobacco Use and Dependence Guideline Panel also suggested a minimum 6-month period as an adequate period of abstinence to assess treatment differences in the longer term, as a brief period of abstinence is unlikely to have a significant health benefit. Any adverse events reported in each trial were also recorded and assessed.

\section{Data extraction and study appraisal}

Two authors (D.T.T. and A.C.W.) independently examined the search results and screened the titles and abstracts, and subsequently the full text reports of all the potentially relevant trials. Two authors (D.T.T. and M.P.) independently abstracted data from all the included trials using a standardised form. Trial methodological quality was also assessed over four domains: concealment of allocation; masking; completeness of follow-up; and use of intention-to-treat analysis. Any differences of opinion were resolved by discussions among all three authors. When necessary, we attempted to contact report authors to clarify uncertainties in the study design and the results or possible duplicate reporting of the same patient group.

\section{Data synthesis}

One author (D.T.T.) used Review Manager (RevMan) 5.0.17 for Windows (Cochrane Collaboration; see www.cc-ims.net/revman) to synthesise summary estimates. Results for dichotomous outcomes were calculated using the Mantel-Haenszel method and expressed as risk ratio (RR) with $95 \%$ confidence intervals, where risk ratio greater than 1.0 favours bupropion treatment. Results for continuous outcomes were expressed as mean difference where measured with the same scale, or standardised mean difference where measured with different scales, calculated using the inverse variance approach, with 95\% confidence intervals. A summary mean difference or standardised mean difference below zero favoured bupropion treatment. We used random effects analysis as this gives a more conservative estimate in the presence of potential heterogeneity. Heterogeneity among trials was estimated using both Cochran $Q$ test and $I^{2}$ statistic. ${ }^{19}$

Subgroup analyses were performed to compare trials where bupropion was used as a single intervention with trials where bupropion was used as an adjunct to other drug therapy, such as nicotine replacement therapy (NRT). Sensitivity analyses were also conducted to assess the effect of different publication types (e.g. a full journal article $v$. a conference abstract) and different dosages of bupropion used.

\section{Results}

\section{Literature search, characteristic and quality of included studies}

We identified and included 21 reports of 7 trials with a total of 260 participants. The process of trial identification is summarised in Fig.1, and the characteristics of all included trials in Table 1. All the reports were in English and all the trials were conducted in the USA, with participants recruited from the community. All studies except on $e^{20}$ included people who expressed a desire to quit smoking and were willing to set a target quit date. Individuals with active substance misuse in addition to nicotine were excluded in all the trials apart from one. ${ }^{20}$

Two trials used bupropion as an adjunct to NRT, ${ }^{21-27}$ whereas the other trials used bupropion as a single-agent drug therapy for smoking cessation. One trial employed a cross-over design and participants received either bupropion or placebo for 3 weeks, then a week without intervention as a washout period, followed by cross-over to the alternative regimen for 3 more weeks. ${ }^{20}$ All trials except one included group psychological intervention in addition to drug treatment. ${ }^{20}$ All trials included a measurement of expired $\mathrm{CO}$ level as biological validation of participants' self-report. Five trials reported follow-up data for at least 6 months from the start of bupropion treatment. ${ }^{21-23,26,28-36}$ One trial reported only as conference proceedings. ${ }^{37,38}$ All studies reported monitoring of mental state before and after bupropion treatment.

Table 2 summaries the methodological quality of these studies regarding masking, completeness of follow-up and use of intention-to-treat analysis. No trial gave details of the method of randomisation or allocation concealment in their reports and we did not receive any clarification from the authors before we submitted this review. The reports of three studies stated that intention-to-treat analysis was used. However, participants who were randomised but dropped out before receiving the study intervention in these three trials were not included in the analysis. ${ }^{23,28,32}$ Four trials explicitly report checking 


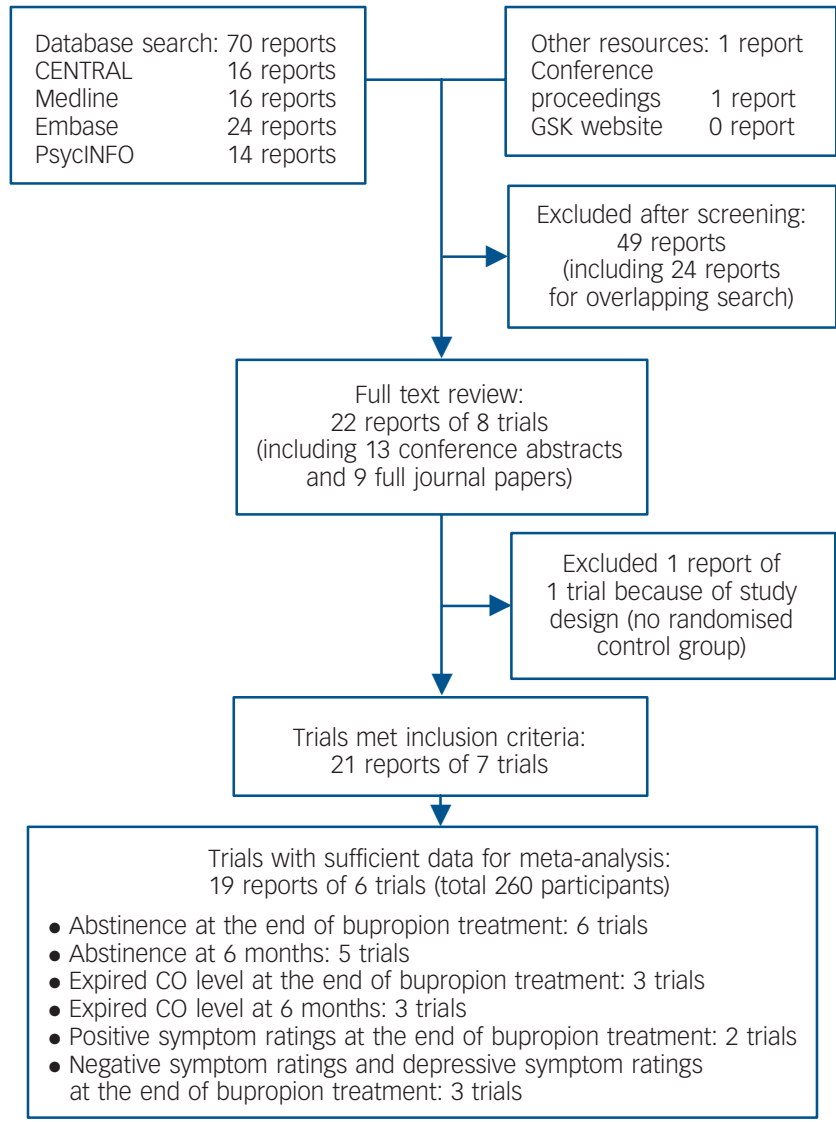

Fig. 1 Summary of the process of identifying randomised trials for inclusion in this systematic review of bupropion for smoking cessation in people with schizophrenia. CO, carbon monoxide. participants' adherence to taking their medication. Placebo was matched in appearance with the bupropion tablet in four studies.

\section{Data synthesis and meta-analysis}

Participants taking bupropion were two and a half times more likely to be abstinent at the end of treatment, compared with those on placebo ( 6 trials, 260 participants, $\mathrm{RR}=2.57$, 95\% CI 1.35 4.88, heterogeneity $P=0.54, I^{2}=0 \%$ ) (Fig. 2). Subgroup analysis revealed that abstinence may be more likely when bupropion was combined with NRT $(\mathrm{RR}=2.92,95 \%$ CI $0.75-11.33)$, compared with using bupropion as the only pharmacotherapy $(\mathrm{RR}=2.77$, 95\% CI 1.05-7.32). Sensitivity analysis showed an increased risk ratio when a trial reported only as a conference abstract ${ }^{38}$ was removed from the analysis $(\mathrm{RR}=3.02,95 \%$ CI $1.45-6.32)$. Similar results were obtained when the trial ${ }^{32}$ using low dose $(150 \mathrm{mg}$ bupropion daily compared with $300 \mathrm{mg}$ daily in other trials) was excluded $(\mathrm{RR}=2.58,95 \%$ CI $1.32-5.02)$.

Abstinence was sustained and unchanged at 6 months after starting bupropion ( 5 trials, 214 participants, $\mathrm{RR}=2.78,95 \% \mathrm{CI}$ 1.02-7.58) (Fig. 3). Subgroup analysis also suggested that maintained abstinence was more likely when bupropion was used together with NRT (2 trials, 110 participants, RR $=3.41,95 \% \mathrm{CI}$ 0.87-13.30) compared with using bupropion alone ( 3 trials, 104 participants, $\mathrm{RR}=2.19,95 \%$ CI $0.50-9.63$ ).

Six trials reported smoking reduction using expired CO level, but only three trials (123 participants) provided sufficient data for meta-analysis. ${ }^{22,28,32}$ At the end of bupropion treatment, there was a significant reduction in the expired CO level of individuals in the bupropion group compared with the control group (mean difference -6.84 parts per million ( $\mathrm{ppm}$ ), 95\% CI -11.11 to $-2.56 \mathrm{ppm}$, heterogeneity $\left.P=0.44, I^{2}=0 \%\right)$. However, at 6 months

Table 1 Characteristics of trials included in this systematic review of bupropion for smoking cessation in people with schizophrenia

\begin{tabular}{|c|c|c|c|c|c|c|}
\hline Trials & Setting & $\begin{array}{l}\text { Participants, } \\
n\end{array}$ & $\begin{array}{l}\text { Dose and duration } \\
\text { of bupropion }\end{array}$ & Co-interventions & $\begin{array}{l}\text { Abstinence } \\
\text { verification }\end{array}$ & Length of follow-up \\
\hline $\begin{array}{l}\text { Evins } \\
(2001)^{32,34,36}\end{array}$ & $\begin{array}{l}\text { Single } \\
\text { centre }\end{array}$ & 19 & $\begin{array}{l}150 \text { mg daily for } \\
12 \text { weeks }\end{array}$ & $\begin{array}{l}\text { Hourly group CBT } \\
\text { for } 9 \text { weeks }\end{array}$ & $\begin{array}{l}\text { Expired co level } \\
<9 \text { ppm or serum } \\
\text { cotinine }<14 \mathrm{ng} / \mathrm{ml}\end{array}$ & 2 years \\
\hline $\begin{array}{l}\text { George } \\
(2002)^{21,26,33,35}\end{array}$ & $\begin{array}{l}\text { Single } \\
\text { centre }\end{array}$ & 32 & $\begin{array}{l}150 \mathrm{mg} \text { daily for first } \\
3 \text { days and then } \\
300 \mathrm{mg} \text { daily for } \\
10 \text { weeks }\end{array}$ & $\begin{array}{l}\text { Hourly group therapy (motivation } \\
\text { enhancement, psychoeducation and } \\
\text { relapse prevention) for } 10 \text { weeks }\end{array}$ & $\begin{array}{l}\text { Expired co level } \\
<10 \mathrm{ppm}\end{array}$ & 6 months \\
\hline $\begin{array}{l}\text { Evins } \\
(2005)^{28-31}\end{array}$ & $\begin{array}{l}\text { Multi- } \\
\text { centre }\end{array}$ & 53 & $\begin{array}{l}150 \mathrm{mg} \text { daily for first } \\
\text { week and } 300 \mathrm{mg} \text { daily } \\
\text { for } 12 \text { weeks }\end{array}$ & Hourly group CBT for 12 weeks & $\begin{array}{l}\text { Expired co level } \\
<9 \mathrm{ppm}\end{array}$ & 24 weeks \\
\hline $\begin{array}{l}\text { Fatemi }^{\mathrm{a}} \\
(2005)^{20}\end{array}$ & $\begin{array}{l}\text { Single } \\
\text { centre }\end{array}$ & 10 & Unclear & Not mentioned & $\begin{array}{l}\text { Monitored expired } \\
\text { co level but } \\
\text { unclear definition } \\
\text { of abstinence }\end{array}$ & $\begin{array}{l}\text { Cross-over design: } \\
3 \text { weeks bupropion/placebo, } \\
1 \text { week washout and } 3 \text { week } \\
\text { placebo/bupropion }\end{array}$ \\
\hline $\begin{array}{l}\text { Evins } \\
(2007)^{22,24}\end{array}$ & $\begin{array}{l}\text { Multi- } \\
\text { centre }\end{array}$ & 51 & $\begin{array}{l}150 \mathrm{mg} \text { daily for first } \\
\text { week and } 300 \mathrm{mg} \\
\text { daily for } 12 \text { weeks }\end{array}$ & $\begin{array}{l}\text { Nicotine patch from week } 4 \\
(21 \mathrm{mg} / \text { day for } 4 \text { weeks, then } \\
14 \mathrm{mg} / \text { day for } 2 \text { weeks, } 7 \mathrm{mg} / \text { day } \\
\text { for another } 2 \text { weeks) + as required } \\
\text { nicotine gum + hourly group CBT } \\
\text { for } 12 \text { weeks }\end{array}$ & $\begin{array}{l}\text { Expired co level } \\
\leqslant 8 \mathrm{ppm}\end{array}$ & 6 months \\
\hline $\begin{array}{l}\text { George } \\
(2008)^{21,23,25-27}\end{array}$ & $\begin{array}{l}\text { Single } \\
\text { centre }\end{array}$ & 59 & $\begin{array}{l}150 \mathrm{mg} \text { daily for } 3 \\
\text { days and then } 300 \mathrm{mg} \\
\text { daily for } 10 \text { weeks }\end{array}$ & $\begin{array}{l}\text { TNP }(21 \mathrm{mg} / 24 \mathrm{~h})+\text { group behavioural } \\
\text { therapy for } 10 \text { weeks ( } 50 \mathrm{~min} \\
\text { each week) }\end{array}$ & $\begin{array}{l}\text { Expired co level } \\
<10 p p m\end{array}$ & 6 months \\
\hline $\begin{array}{l}\text { Weiner } \\
(2007)^{37,38}\end{array}$ & $\begin{array}{l}\text { Multi- } \\
\text { centre }\end{array}$ & 46 & $\begin{array}{l}300 \text { mg daily for } \\
12 \text { weeks (week } 2 \\
\text { to week 14) }\end{array}$ & Group therapy for 9 weeks & $\begin{array}{l}\text { Expired co level } \\
<10 \text { ppm }\end{array}$ & 14 weeks \\
\hline
\end{tabular}




\begin{tabular}{|c|c|c|c|c|c|}
\hline Trials & Masking & Intention-to-treat analysis & Completeness of follow-up & $\begin{array}{l}\text { Adherence } \\
\text { monitoring }\end{array}$ & $\begin{array}{l}\text { Matching of } \\
\text { bupropion } \\
\text { and placebo }\end{array}$ \\
\hline $\begin{array}{l}\text { Evins } \\
(2001)^{32,34,36}\end{array}$ & $\begin{array}{l}\text { Double-blind (explicitly stated } \\
\text { that participants were masked; } \\
\text { otherwise unclear) }\end{array}$ & $\begin{array}{l}\text { Explicitly stated in the report } \\
\text { but it was not confirmed on } \\
\text { study assessment }\end{array}$ & $\begin{array}{l}1 / 19 \text { dropped out prior to } \\
\text { medication (not included in } \\
\text { analysis) }\end{array}$ & Yes & Yes \\
\hline $\begin{array}{l}\text { George } \\
(2002)^{21,26,37,39}\end{array}$ & $\begin{array}{l}\text { Explicitly stated that participants, } \\
\text { investigators and outcome } \\
\text { assessors were masked to } \\
\text { intervention }\end{array}$ & $\begin{array}{l}\text { Specifically reported by the } \\
\text { authors and this was confirmed } \\
\text { on study assessment }\end{array}$ & $5 / 32$ dropped out during trial & Unclear & Yes \\
\hline Evins $(2005)^{28-31}$ & $\begin{array}{l}\text { Double-blind but details } \\
\text { uncertain }\end{array}$ & $\begin{array}{l}\text { Explicitly stated in the report } \\
\text { but it was not confirmed on } \\
\text { study assessment }\end{array}$ & $\begin{array}{l}4 \text { dropped out prior to } \\
\text { medication (not included in } \\
\text { analysis); } 10 / 53 \text { dropped out } \\
\text { at week } 12 ; 9 \text { more dropped } \\
\text { out at week } 24\end{array}$ & Yes & Yes \\
\hline Fatemi $(2005)^{20}$ & $\begin{array}{l}\text { Double-blind (both participants } \\
\text { and research staff) }\end{array}$ & $\begin{array}{l}\text { Not stated and there was lack } \\
\text { of confirmed intention-to-treat } \\
\text { analysis on study assessment }\end{array}$ & $\begin{array}{l}1 / 10 \text { dropped out from the } \\
\text { study }\end{array}$ & Unclear & Unclear \\
\hline Evins $(2007)^{22,24}$ & $\begin{array}{l}\text { Explicitly stated that participants, } \\
\text { investigators and outcome } \\
\text { assessors were masked to } \\
\text { intervention }\end{array}$ & $\begin{array}{l}\text { Specifically reported by the } \\
\text { authors and this was confirmed } \\
\text { on study assessment }\end{array}$ & $\begin{array}{l}\text { 5/25 (bupropion) and 8/26 } \\
\text { (control) dropped out }\end{array}$ & Yes & Unclear \\
\hline $\begin{array}{l}\text { George } \\
(2008)^{21,23,25-27}\end{array}$ & $\begin{array}{l}\text { Double-blind but details } \\
\text { uncertain }\end{array}$ & $\begin{array}{l}\text { Explicitly stated in the report but } \\
\text { it was not confirmed on study } \\
\text { assessment }\end{array}$ & $\begin{array}{l}\text { 1/59 dropped out prior } \\
\text { medication; } 6 / 29 \text { (bupropion) } \\
\text { and } 10 / 29 \text { (control) dropped } \\
\text { out during trial }\end{array}$ & Yes & Yes \\
\hline Weiner $(2007)^{37,38}$ & $\begin{array}{l}\text { Double-blind but details } \\
\text { uncertain }\end{array}$ & $\begin{array}{l}\text { Intention-to-treat analysis was } \\
\text { not explicitly stated but it was } \\
\text { confirmed on study assessment }\end{array}$ & $\begin{array}{l}\text { 2/46 dropped out prior to } \\
\text { medication, } 9 / 46 \text { dropped out } \\
\text { during trial }\end{array}$ & Unclear & Unclear \\
\hline
\end{tabular}

after the start of bupropion treatment there was no significant difference in the expired CO level (mean difference $-5.73 \mathrm{ppm}$, $95 \% \mathrm{CI}-18.09$ to $6.63 \mathrm{ppm}$ ) but there was substantial heterogeneity among trials $\left(P=0.003, I^{2}=83 \%\right)$, largely because one trial reported a higher expired CO level in the bupropion group at 6 months. ${ }^{28}$ The three trials reporting incomplete data for the expired CO level also favoured bupropion at the end of the treatment. ${ }^{20,33,38}$

All trials reported some measures of mental state before and after bupropion. Compared with placebo, bupropion did not cause any significant deterioration of positive, negative and depressive symptoms in people with schizophrenia when it was used as an aid for smoking cessation. Two studies provided sufficient data for estimation of change of positive symptoms $(85 \text { participants })^{28,33}$ and one additional study also provided sufficient data to estimate the effect of bupropion on negative and depressive symptoms (136 participants). ${ }^{22}$ There was no evidence of a difference for bupropion compared with control in positive symptoms (standardised mean difference -0.24 , $95 \%$ CI -0.66 to 0.19 ), negative symptoms (standardised mean difference $-0.12,95 \% \mathrm{CI}-0.46$ to 0.22 ) or depressive symptoms (standardised mean difference $-0.16,95 \% \mathrm{CI}-0.50$ to 0.18 ).

Regarding other adverse effects of bupropion, no trials reported any seizures. The prevalence of dry mouth was significantly higher in the bupropion group compared with the control group in one study $(P<0.05) .{ }^{33}$ The same research group, in a second study, reported significant differences on concentration, jitteriness, light-headedness, muscle stiffness and frequent nocturnal awakening in the bupropion group. ${ }^{23}$ Of 59 participants, 3 ( 2 in the placebo group and 1 in the bupropion group) had a psychotic breakdown during the trial, but the authors concluded these psychotic breakdowns were unrelated to bupropion. In another study, one participant who was randomised to bupropion also had an allergic reaction to the medication. ${ }^{28}$ In a different trial, two people on bupropion and NRT dropped out from the trial because of insomnia and dizziness. ${ }^{22}$ One trial did not mention any adverse effects in the reports ${ }^{37,38}$ and the remaining trials either reported 'no serious adverse events ${ }^{32}$ or 'no indications of increased side effects. ${ }^{20}$

\section{Discussion}

Smokers with schizophrenia who used bupropion to aid smoking cessation had a two and a half times higher rate of abstinence at the end of the drug therapy compared with those who did not use bupropion. Abstinence was sustained at 6 months after the treatment, even though all participants took the drug for 12 weeks or less, and the results were consistent among trials. There is no evidence from this meta-analysis to suggest that smokers with schizophrenia who used bupropion for smoking cessation differed significantly in positive, negative and depressive symptoms of schizophrenia from smokers on placebo. Although some side-effects of treatment that might be important to individuals were noted, there were no significant serious adverse clinical events such as seizure.

This is the first review showing that bupropion can increase the rate of smoking abstinence in smokers with schizophrenia. Only one study demonstrated a statistically significant increase in the abstinence rate with bupropion ${ }^{23}$ and the other studies showed non-significant trends of the efficacy of bupropion in people with schizophrenia. This was likely as a result of the small sample size in each individual study. By pooling the data together in the meta-analysis, this systematic review revealed the beneficial effect of bupropion in smoking abstinence among individuals with schizophrenia.

In addition, at the end of treatment, the expired CO level in the bupropion group was $6.84 \mathrm{ppm}$ lower than in the placebo group. Reduction of the expired $\mathrm{CO}$ level is a good indicator of 


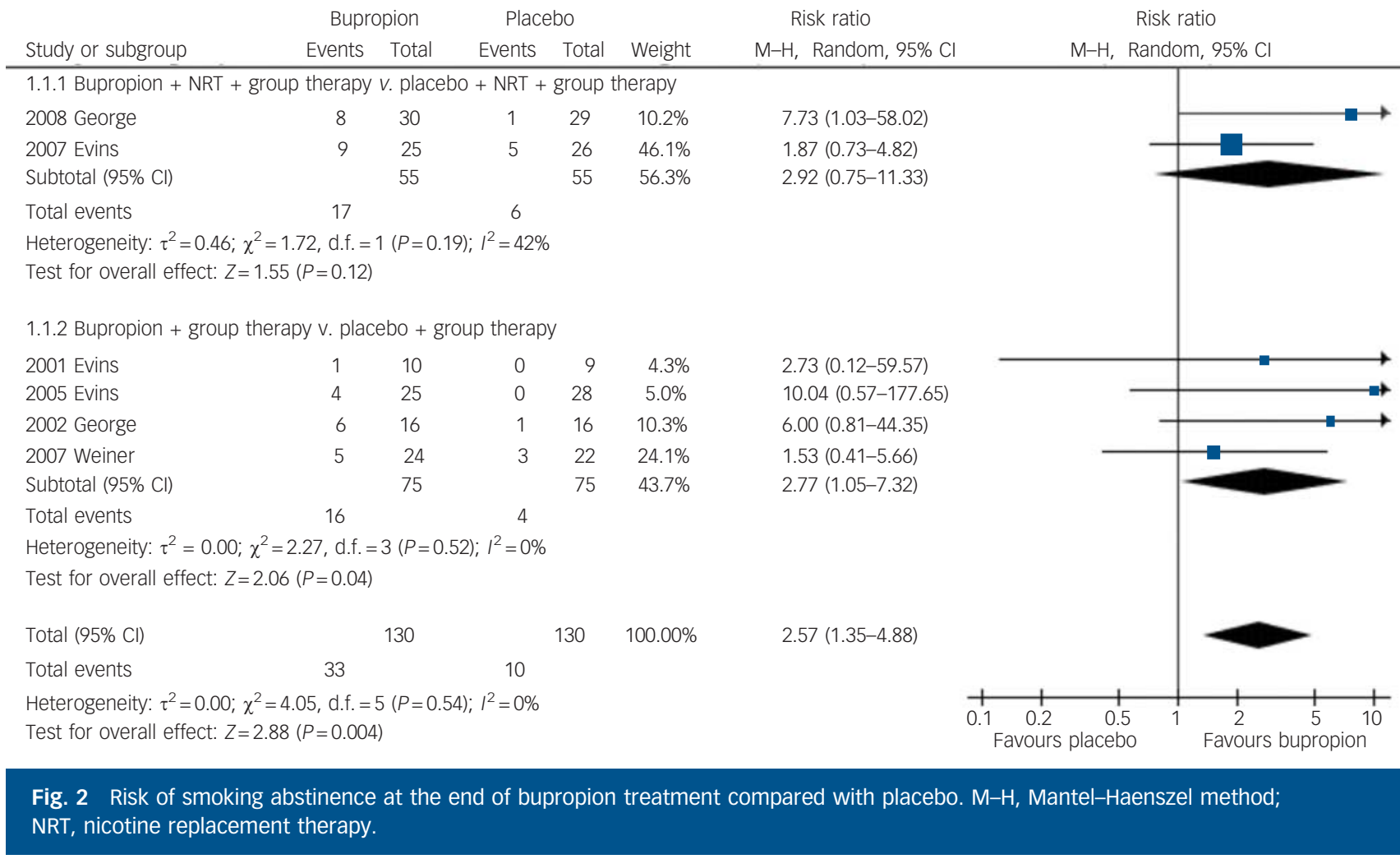

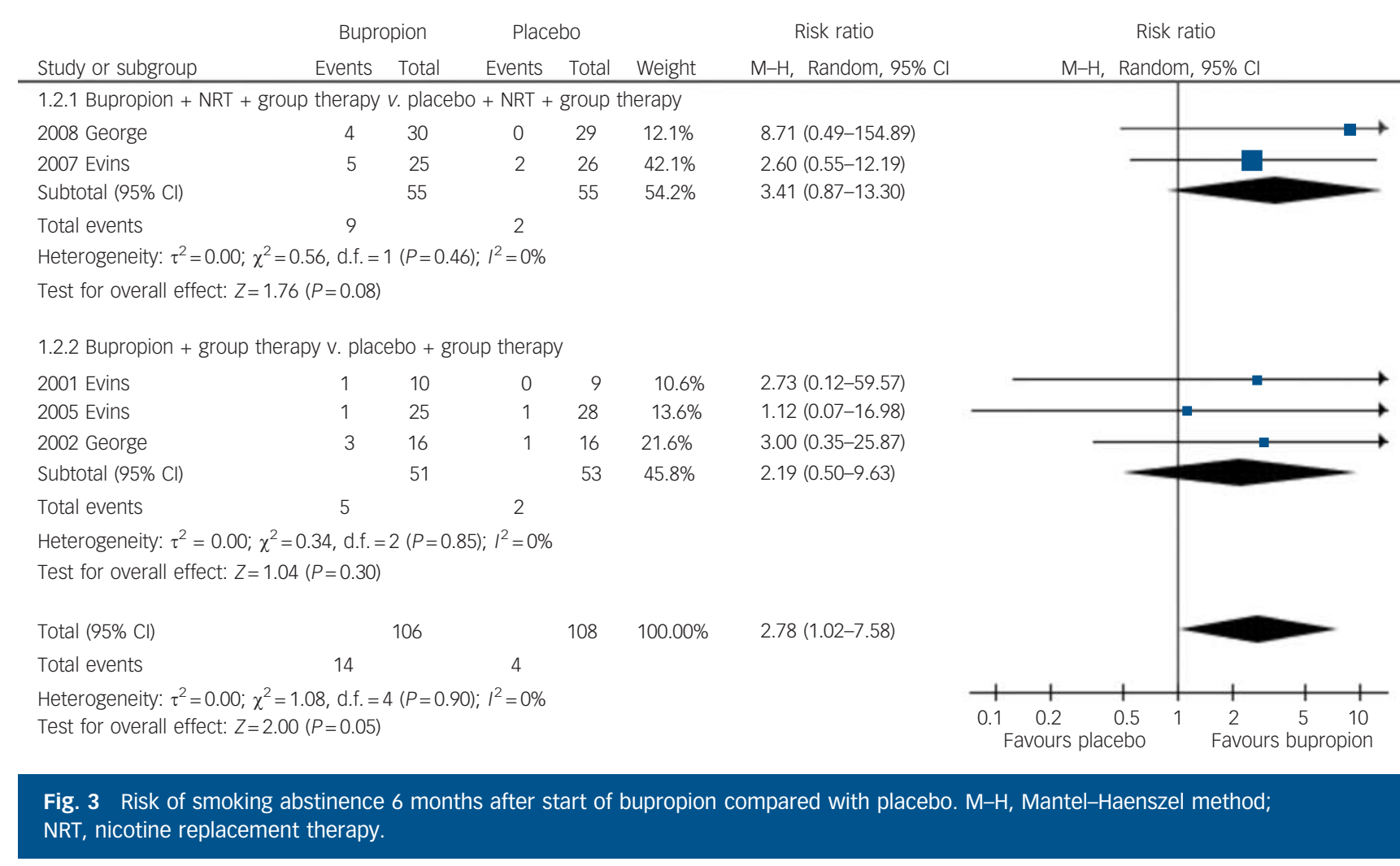

smoking reduction and this result suggests that bupropion is also effective in reducing cigarette smoking. Evidence from this metaanalysis did not show a sustained effect at 6 months. However, only three trials provided sufficient data for meta-analysis and there was also a significant heterogeneity among trials for the expired CO level at 6 months.

\section{Clinical implications}

There is substantial evidence suggesting that bupropion is beneficial for smoking cessation in the general public. ${ }^{9}$ Based on the best currently available evidence, the results of this systematic review support the effectiveness of bupropion in smoking 
cessation in individuals with schizophrenia. Smoking cessation and even reduction may have a significant effect on the reduction of cardiovascular risk. ${ }^{39,40}$ Individuals with schizophrenia have a much higher risk of developing cardiovascular disease, which contributes to the increased rate of premature mortality compared with the general population. ${ }^{41,42}$ There are other factors contributing to the elevated cardiovascular risk in this group of people. These include unhealthy diet, poor engagement with medical care and physical inactivity resulting in obesity. ${ }^{43,44}$ Increased prevalence of smoking among people with schizophrenia also contributes substantially to their higher cardiovascular risk. ${ }^{45}$ Furthermore, atypical antipsychotics can cause significant weight gain, glucose dysregulation and lipid abnormality, which can further raise the already high risk of cardiovascular disease. ${ }^{46-48}$ Apart from cardiovascular diseases, chronic cigarette smoking in people with schizophrenia has also been reported as an important contributing factor to the higher morbidity and mortality from malignancy and respiratory diseases. ${ }^{49,50}$

Stopping or reducing smoking in people with schizophrenia is a priority for healthcare professionals and for public health policy makers. Recent guidelines on smoking cessation have acknowledged this by including special guidelines for those with schizophrenia. ${ }^{18,51}$ Our review has shown that there is no evidence to support exacerbation of psychosis secondary to the use of bupropion in schizophrenia. In the general population, seizure is a recognised side-effect of bupropion, with a rate of about 1 in 1000. There have been some concerns among clinicians that the risk of seizure with bupropion may potentially be much higher for people with schizophrenia, as many antipsychotic medications are already well-known to increase the risk of developing seizure and co-intervention with bupropion may further exacerbate this risk. There was no report of seizure in any of the included trials. However, the total number of individuals randomised to bupropion was relatively small (130 participants). Hence, the evidence should be interpreted with caution, and the relationship between seizure and bupropion in schizophrenia needs further confirmation. Nevertheless, the results of this review can inform further guideline development and revisions for smoking cessation in schizophrenia, which is particularly important in the context of enforced smoking bans including mental health units in the $\mathrm{UK} .^{52}$

\section{Implications for future research}

Although smokers with schizophrenia who used bupropion were more likely to abstain from smoking 6 months after the start of drug treatment, more research is necessary to examine whether abstinence can be maintained over a prolonged period. Only one study followed patients for 2 years after bupropion intervention. In that study, people with schizophrenia who reduced smoking significantly after bupropion were more likely to abstain from smoking after 2 years. ${ }^{36}$ In addition, the sample size of each study was also relatively small (the largest sample size was 30 in one arm). Using the crude abstinence rate of about $8 \%$ in the placebo group and the meta-analytical risk ratio of 2.57 from this review of cessing smoking after taking bupropion, the calculated required minimum sample size for a trial of $5 \%$ statistically significance and $80 \%$ power is 136 (calculation according to Statcalc in EpiInfo version 3.5.1 for Windows (Centers for Disease Control and Prevention, Atlanta, see www.cdc.gov/epiinfo/ epiinfo.htm)). Hence, future study design should focus on a larger sample size as well as a longer follow-up such as a year. Collaboration between multiple research centres may be necessary because of the potential difficulties in recruiting and following up individuals with schizophrenia for clinical trials.

Moreover, we did not identify any study that directly compares bupropion with NRT for smoking cessation in schizophrenia. There is some evidence from both direct and indirect comparisons that the efficacy of bupropion and NRT is similar in the general population. ${ }^{9}$ However, previous studies have suggested that smokers with normal dopaminergic function showed a better response to bupropion, whereas genotypes that are associated with impaired dopaminergic systems may have better outcomes with NRT. ${ }^{53,54}$ People with schizophrenia have a dysfunctional dopaminergic system and adequately powered new RCTs that directly compare bupropion with NRT may answer the question whether these individuals respond differently to bupropion and NRT. The results of the subgroup analyses in this meta-analysis suggested that combining bupropion and NRT may increase the smoking abstinence rate compared with NRT alone. However, these analyses should be interpreted with caution because of the small number of studies involved. Nonetheless, further biochemical research regarding the mechanisms of the action of bupropion could give a better insight about the role of different neurotransmitters in nicotine addiction and withdrawal.

There are several economic analyses suggesting that bupropion is a cost-effective treatment for smoking cessation in the general public and may be more cost-effective than NRT. ${ }^{55-57}$ None of the trials we identified included any health economic outcomes, and we are not aware of any economic analysis to investigate the cost-effectiveness of bupropion in treating nicotine dependence in people with schizophrenia. An economic analysis would allow the construction of a decision analysis algorithm, which could aid clinicians, patients and policy-makers in making evidence-based treatment decisions.

\section{Strengths and limitations}

There are a few issues to consider in this review. The number of studies was relatively small and there were some methodological weaknesses in the included trials. For example, only three trials reported using appropriate intention-to-treat analyses and we were unable to clarify methods further with the authors of other trials. Monitoring of adherence to taking medication was only reported in four trials. The results of this review also may not apply to all the people with schizophrenia, as most of the included trials explicitly excluded individuals with schizophrenia and comorbid substance misuse other than nicotine.

However, the strength of this systematic review was the use of robust methodology, including a comprehensive search strategy and an appropriate meta-analytic technique to answer an important clinical question. The results of this review should advance our current understanding of the efficacy and potential harmful effects of bupropion for smoking cessation in schizophrenia. This is the first review showing that bupropion can increase the rate of smoking abstinence in smokers with schizophrenia without jeopardising their mental state.

\footnotetext{
Daniel Tai-yin Tsoi, MBChB, MSC, MRCPsych, FHKCPsych, FHKAM(Psychiatry), Academic Clinical Psychiatry, University of Sheffield, Sheffield; London School of Hygiene and Tropical Medicine, London; and Division of Psychiatry, Queens Medica Centre, Nottinghamshire Healthare NHS Trust, NOting Centre, Notinghical Medicine, London; and Division of PSychiary, Queens Medica MPH, School of Public Health, University of Sydne, New South Wales, Australia; Angela Claire Webster, MBBS, MM(Clin Epid), MRCP(UK), PhD, School of Public Health, University of Sydney, New South Wales, Australia, and London School of Hygiene and Tropical Medicine, London, UK

Correspondence: Daniel Tai-yin Tsoi, Division of Psychiatry, A Floor, South Block, Queen's Medical Centre, Nottingham NG7 2UH, UK. Email: t.tsoi@sheffield.ac.uk

First received 11 Mar 2009, final submission 4 Nov 2009, accepted 17 Feb 2010
} 


\section{References}

1 World Health Organization. Policy Recommendations on Smoking Cessation and Treatment of Tobacco Dependence. WHO, 2003.

2 de Leon J, Diaz FJ. A meta-analysis of worldwide studies demonstrates an association between schizophrenia and tobacco smoking behaviors. Schizophr Res 2005; 76: 135-57.

3 Olincy A, Young DA, Freedman R. Increased levels of the nicotine metabolite cotinine in schizophrenic smokers compared to other smokers. Biol Psychiatry 1997; 42: 1-5.

4 Kelly C, McCreadie RG. Smoking habits, current symptoms, and premorbid characteristics of schizophrenic patients in Nithsdale, Scotland. Am J Psychiatry 1999; 156: 1751-7.

5 Williams JM, Ziedonis DM, Abanyie F, Steinberg ML, Foulds J, Benowitz NL. Increased nicotine and cotinine levels in smokers with schizophrenia and schizoaffective disorder is not a metabolic effect. Schizophr Res 2005; 79: 323-35

6 Adler LE, Hoffer LD, Wiser A, Freedman R. Normalization of auditory physiology by cigarette smoking in schizophrenic patients. Am J Psychiatry 1993; 150: 1856-61.

7 Sacco KA, Bannon KL, George TP. Nicotinic receptor mechanisms and cognition in normal states and neuropsychiatric disorders J Psychopharmacol 2004; 18: 457-74.

8 Addington J, el-Guebaly N, Addington D, Hodgins D. Readiness to stop smoking in schizophrenia. Can J Psychiatry 1997; 42: 49-52.

9 Hughes JR, Stead LF, Lancaster T. Antidepressants for smoking cessation. Cochrane Database Syst Rev 2007; 1: CD000031.

10 Stahl SM, Pradko JF, Haight BR, Modell JG, Rockett CB, Learned-Coughlin S A review of the neuropharmacology of bupropion, a dual norepinephrine and dopamine reuptake inhibitor. Prim Care Companion J Clin Psychiatry 2004; 6 : 159-66

11 Fryer JD, Lukas RJ. Noncompetitive functional inhibition at diverse, human nicotinic acetylcholine receptor subtypes by bupropion, phencyclidine, and ibogaine. J Pharmacol Exp Ther 1999; 288: 88-92.

12 Cryan JF, Bruijnzeel AW, Skjei KL, Markou A. Bupropion enhances brain reward function and reverses the affective and somatic aspects of nicotine withdrawal in the rat. Psychopharmacology (Berl) 2003; 168: 347-58.

13 Strasser K. Smoking Reduction and Cessation for People with Schizophrenia: Guidelines for General Practitioners. SANE Australia \& Department of Psychiatry, University of Melbourne, 2001.

14 World Health Organization. The ICD-10 Classification of Mental and Behavioural Disorders: Clinical Descriptions and Diagnostic Guidelines. WHO, 1992.

15 American Psychiatric Association. Diagnostic and Statistical Manual of Mental Disorders (4th edn) (DSM-IV). APA, 1994.

16 Dixon L. Dual diagnosis of substance abuse in schizophrenia: prevalence and impact on outcomes. Schizophr Res 1999; 35: S93-100.

17 West R, Hajek P, Stead L, Stapleton J. Outcome criteria in smoking cessation trials: proposal for a common standard. Addiction 2005; 100: 299-303.

18 Fiore M, Jaén C, Baker T, Bailey W, Benowitz NL, Curry S, et al. Treating Tobacco Use and Dependence: 2008 Update - Clinical Practice Guideline. United States Department of Health and Human Services, 2008.

19 Higgins JP, Thompson SG, Deeks JJ, Altman DG. Measuring inconsistency in meta-analyses. BMJ 2003; 327: 557-60.

20 Fatemi S, Stary J, Hatsukami D, Murphy S. A double-blind placebo-controlled cross over trial of bupropion in smoking reduction in schizophrenia. Schizophr Res 2005; 76: 353-6.

21 George TP, Hitsman B, Papandonatos GD, Sacco KA, Vessicchio JC, Dudas M, et al. Predictors of smoking cessation in schizophrenia: analysis of data from three sequential controlled clinical trials. Neuropsychopharmacol 2004; 29 (suppl 1): s103.

22 Evins A, Cather C, Culhane MA, Birnbaum A, Horowitz J, Hsieh E, et al. A 12 week double-blind, placebo-controlled study of bupropion SR added to highdose dual nicotine replacement therapy for smoking cessation or reduction in schizophrenia. J Clin Psychopharmacol 2007; 27: 380-6.

23 George TP, Vessicchio JC, Sacco KA, Weinberger AH, Dudas MM, Allen TM, et al. A placebo-controlled trial of bupropion combined with nicotine patch for smoking cessation in schizophrenia. Biol Psychiatry 2008; 63: 1092-6.

24 Evins $A E$, Cather $C$, Culhane M, Birnbaum AS, Horowitz J, Hsieh E, et al. A placebo-controlled study of bupropion SR added to high dose nicotine replacement therapy for smoking cessation or reduction in schizophrenia Nicotine Tob Res 2007; 9 (suppl 2): s101.

25 George TP, Vessicchio JC, Weinberger AH, Sacco KA. Sustained-release bupropion combined with transdermal nicotine patch for smoking cessation in schizophrenia. Society for Research on Nicotine and Tobacco 13th Annual Meeting. Society for Research on Nicotine and Tobacco, 2007 (http:// www.srnt.org/meeting/2007/pdf/onsite/2007SRNTAbstracts-FINAL.pdf).

26 Sacco KA, Hitsman B, Papandonatos GD, Vessicchio JC, Dudas MM, Termine A, et al. Predictors of smoking cessation in schizophrenia: analysis of data from three sequential controlled clinical trials. Society for Research on Nicotine and Tobacco 10th Annual Meeting Society for Research on Nicotine and Tobacco, 2004 (http://63.84.94.99/srnt/abstract/2004/a/ retrieveresponse.lasso).

27 George TP, Vessicchio J, Allen T, Weinberger A, Sacco KA. A randomized, double-blind, placebo-controlled trial of sustained-release bupropion combined with transdermal nicotine patch for smoking cessation in schizophrenia: neuropsychological predictors of treatment outcome. Neuropsychopharmacol 2006; 31 (suppl 1): S254-5.

28 Evins A, Cather C, Deckersbach T, Freudenreich O, Culhane MA, OlmShipman CM, et al. A double-blind placebo-controlled trial of bupropion sustained-release for smoking cessation in schizophrenia. J Clin Psychopharmacol 2005; 25: 218-25

29 Evins A, Deckersbach T, Cather C, Freudenreich O, Culhane MA, Henderson $\mathrm{DC}$, et al. Independent effects of tobacco abstinence and bupropion on cognitive function in schizophrenia. J Clin Psychiatry 2005; 66: 1184-90.

30 Evins AE, Cather C, Culhane M, Freudenreich O, Rigotti NA, Goff DC. Smoking cessation in schizophrenia: a double blind placebo controlled trial of bupropion SR added to cognitive behavioral therapy. Biological Psychiatry 2004; 55: 226S.

31 Evins AE, Cather C, Goff DC, Olm-Shipman C, Rigotti NA. A placebo controlled trial of bupropion SR for smoking cessation in schizophrenia. Society for Research on Nicotine and Tobacco 9th Annual Meeting. Society for Research on Nicotine and Tobacco, 2003 (http://63.84.94.99/srnt/abstract/ $\mathrm{r} /$ retrieveresponse.lasso?-MaxRecords=1\&-SortField=Abstract_Title\&SortOrder=ascending\&-Op $=c n \& A b s t r a c t \_T i t l e=\&-O p=c n \& A b s t r a c t=\&-O p=$ cn\&Authors=evins\&-SkipRecords=0).

32 Evins A, Mays VK, Rigotti NA, Tisdale T, Cather C, Goff DC. A pilot trial of bupropion added to cognitive behavioral therapy for smoking cessation in schizophrenia. Nicotine Tob Res 2001; 3: 397-403.

33 George TP, Vessicchio JC, Termine A, Bregartner TA, Feingold A, Rounsaville $B J$, et al. A placebo controlled trial of bupropion for smoking cessation in schizophrenia. Biol Psychiatry 2002; 52: 53-61.

34 Evins A, Cather C, Goff DC, Rigotti NA. Increased smoking cessation and reduction: two years following a smoking cessation trial in patients with schizophrenia. Society for Research on Nicotine and Tobacco 9th Annual Meeting. Society for Research on Nicotine and Tobacco, 2003 (http:// 63.84.94.99/srnt/abstract/a/retrieveresponse.lasso).

35 Vessicchio JC, Termine A, Bregartner TA, George TP. Bupropion versus placebo for smoking cessation in schizophrenia. Drug Alcohol Depend 2002; 66: $\mathrm{s} 187$.

36 Evins AE, Cather C, Rigotti NA, Freudenreich O, Henderson DC, Olm-Shipman $\mathrm{CM}$, et al. Two-year follow-up of a smoking cessation trial in patients with schizophrenia: increased rates of smoking cessation and reduction. J Clin Psychiatry 2004; 65: 307-11.

37 Weiner E, Buchanan R, Gold J, Ball P, Bennett M. A comparison of bupropion SR and placebo for smoking cessation in schizophrenia. Schizophr Res 2003; 60: $305-6$.

38 Weiner E, Ball MP, Buchanan R, Gold JM. A comparison of bupropion SR and placebo for smoking cessation. Schizophr Bull 2007; 33: 465.

39 Eliasson B, Hjalmarson A, Kruse E, Landfeldt B, Westin A. Effect of smoking reduction and cessation on cardiovascular risk factors. Nicotine Tob Res 2001; 3: 249-55.

40 Hatsukami DK, Kotlyar M, Allen S, Jensen J, Li S, Le C, et al. Effects of cigarette reduction on cardiovascular risk factors and subjective measures. Chest 2005; 128: 2528-37.

41 Hennekens $\mathrm{CH}$, Hennekens AR, Hollar D, Casey DE. Schizophrenia and increased risks of cardiovascular disease. Am Heart J 2005; 150: 1115-21.

42 Osby U, Correia N, Brandt L, Ekbom A, Sparen P. Mortality and causes of death in schizophrenia in Stockholm county, Sweden. Schizophr Res 2000; 45: $21-8$.

43 Daumit GL, Goldberg RW, Anthony C, Dickerson F, Brown CH, Kreyenbuhl J, et al. Physical activity patterns in adults with severe mental illness. J Nerv Ment Dis 2005; 193: 641-6.

44 Strassnig M, Brar JS, Ganguli R. Nutritional assessment of patients with schizophrenia: a preliminary study. Schizophr Bull 2003; 29: 393-7.

45 McCreadie RG. Diet, smoking and cardiovascular risk in people with schizophrenia. Descriptive study. Br J Psychiatry 2003; 183: 534-9.

46 Newcomer JW, Haupt DW. The metabolic effects of antipsychotic medications. Can J Psychiatry 2006; 51: 480-91. 
47 Meyer JM, Koro CE. The effects of antipsychotic therapy on serum lipids: a comprehensive review. Schizophr Res 2004; 70: 1-17.

48 Marder SR, Essock SM, Miller AL, Buchanan RW, Casey DE, Davis JM, et al. Physical health monitoring of patients with schizophrenia. Am J Psychiatry 2004; 161: 1334-49.

49 Brown S, Inskip H, Barraclough B. Causes of the excess mortality of schizophrenia. Br J Psychiatry 2000; 177: 212-7.

50 Lichtermann D, Ekelund J, Pukkala E, Tanskanen A, Lonnqvist J. Incidence of cancer among persons with schizophrenia and their relatives. Arch Gen Psychiatry 2001; 58: 573-8.

51 Zwar N, Richmond R, Borland R, Peters M, Stilman S, Litt J, et al. Smoking cessation Pharmacotherapy: An Update for Health Professionals. Royal Australian College of General Practitioners, 2007.

52 Department of Health. Choosing Health: Making Healthier Choices Easier. Department of Health, 2004
53 David SP, Brown RA, Papandonatos GD, Kahler CW, Lloyd-Richardson EE, Munafo MR, et al. Pharmacogenetic clinical trial of sustained-release bupropion for smoking cessation. Nicotine Tob Res 2007; 9: 821-33.

54 Lerman C, Jepson C, Wileyto EP, Epstein LH, Rukstalis M, Patterson F, et al. Role of functional genetic variation in the dopamine D2 receptor (DRD2) in response to bupropion and nicotine replacement therapy for tobacco dependence: results of two randomized clinical trials. Neuropsychopharmacology 2006; 31: 231-42.

55 Shearer J, Shanahan M. Cost effectiveness analysis of smoking cessation interventions. Aust N Z J Public Health 2006; 30: 428-34.

56 Cornuz J, Pinget C, Gilbert A, Paccaud F. Cost-effectiveness analysis of the first-line therapies for nicotine dependence. Eur J Clin Pharmacol 2003; 59: 201-6.

57 Bertram MY, Lim SS, Wallace AL, Vos T. Costs and benefits of smoking cessation aids: making a case for public reimbursement of nicotine replacement therapy in Australia. Tob Control 2007; 16: 255-60.

\section{0 \\ From patient to service user}

\section{David Brunskill}

For doctors, trained and privileged to accept varying degrees of responsibility for another's health problems, changing the terms can feel like a loss of personal identity for both parties. Recovery-oriented practice highlights the importance of the language we use and its relationship to personal meaning, and has much to offer.

However, its scope can make a cow-catcher on the front of a road train look discriminating. If we discard traditional language, do we risk terminally betraying our medical roots and their values? Would doing so not simply confirm the perceived divisions between mental and physical health, and inadvertently compound stigma? 